\title{
Water Quality Regulations in the Chesapeake Bay: Working to More Precisely Estimate Nutrient Loading Rates and Incentivize Best Management Practices in the Nursery and Greenhouse Industry
}

\author{
John C. Majsztrik ${ }^{\mathbf{1}}$ and John D. Lea-Cox \\ Department of Plant Science and Landscape Architecture, 2102 Plant Sciences Building, University \\ of Maryland, College Park, MD 20742
}

Additional index words. Chesapeake Bay, nitrogen, nutrient trading, phosphorus, sediment, total maximum daily load (TMDL)

\begin{abstract}
Restoration efforts in the Chesapeake Bay recently intensified with the 2010 introduction of federal total maximum daily load (TMDL) limits for all 92 bay watershed segments. These regulations have specific, binding consequences if any of the six states or the District of Columbia fail to meet interim goals, including loss of federal dollars for various programs and increasing regulation of point sources, if non-point source (agricultural and urban) nutrient reduction goals are not met in the watershed. As part of the effort to better understand and account for non-point sources of pollution in the watershed, a team of agricultural experts from across the bay region was recently assembled, including the nursery industry. The goal of this panel was to inform stakeholders and policymakers about the inputs and management practices used across all Bay states. To increase both the precision and accuracy of loading rate estimates, more precise information should guide future iterations of the Chesapeake Bay model. A more accurate accounting of land area by operation type (e.g., greenhouse, container, and field) is a primary issue for the nursery and greenhouse industry, because the current Chesapeake Bay model relies on USDA agricultural census data, which does not separate container and field production, which have very different nutrient and irrigation practices. Field operations also typically account for a higher percentage of production area in each state, which may skew model results. This is very important because the type of operation (field, container-nursery, or greenhouse operation) has a significant impact on plant density, types of fertilizer used, and application rates, which combine with irrigation and water management practices to affect potential nutrient runoff. It is also important to represent a variety of implemented best management practices (BMPs) in the Chesapeake Bay model such as vegetated buffer strips, sediment ponds, controlled-release fertilizer, and accurately assess how these mitigate both nutrient and sediment runoff from individual operations. There may also be opportunities for growers who have implemented BMPs such as low-phosphorus slow-release fertilizers (SRF), precision irrigation, etc., to gain additional revenue through nutrient trading. Although there are currently some questions about how nutrient trading will work, this could provide additional incentives for further implementation of BMPs by both ornamental and other agricultural growers. It is possible that the TMDL process currently being implemented throughout the Chesapeake Bay will be used as a remediation process for other impaired estuarine water bodies, which have similar water-use regulations and issues. The lessons learned about the Chesapeake Bay model in general, and for the nursery and greenhouse industry in particular, will likely provide guidance for how we can be proactive in reducing environmental impacts and protect the economic viability of ornamental growers in the future.
\end{abstract}

\section{A BRIEF HISTORY OF CHESAPEAKE BAY RESTORATION EFFORTS}

For almost 30 years, the Chesapeake Bay has been targeted for water quality improvements with the goal of removing the Bay and its tributaries from the Environmental Protection Agency (EPA) 303(d) impaired waters list. During that time, a number of plans and agreements were put into place to achieve

Received for publication 4 Mar. 2013. Accepted for publication 31 May 2013

Special thanks to Drs. Sarah White, Don Merhaut, and two anonymous reviewers for their critical review and suggestions for improving this manuscript. Also a special thank you to Sarah White and ASHS for organizing and hosting this colloquium series.

This paper was part of the colloquium series "Regulating Water Quality: Current Legislation, Future Impacts" held 1 Aug. 2012 at the ASHS Conference, Miami, FL, and sponsored by the Nursery Crops, Water Utilization and Management, Waste Utilization in Horticulture, and Floriculture Working Group.

${ }^{1}$ To whom reprint requests should be addressed; e-mail jcmajsz@umd.edu. that goal. The first Chesapeake Bay Agreement was signed in 1983 (Chesapeake Bay Partnership, 1983) and was a voluntary partnership among Maryland, Pennsylvania, Virginia, Washington, DC, and the EPA. This was soon replaced by an updated agreement in 1987, because it had no specific goals or methods to reach those goals. The 1987 agreement sought to reduce the nitrogen $(\mathrm{N})$ and phosphorus (P) loads entering the Bay by $40 \%$ by the year 2000 (Chesapeake Executive Council, 1987). This agreement included deadlines and reduction goals, but there were no consequences associated with the failure to meet those goals, and participation was voluntary. During this time, some moderate improvements in Bay health were achieved through education, habitat restoration, species management plans, increased implementation of BMPs, updates to wastewater treatment plants, and a reduction of heavy metals and other toxins (Chesapeake Executive Council, 1987).

The 1992 amendment expanded restoration efforts to tributaries instead of just the main stem of the Bay and acknowledged that a reduction of upstream pollution would benefit the Bay overall (Chesapeake Executive
Council, 1992). Additionally, there were increased efforts to control non-point source pollution, which was primarily attributed to agriculture, but urban sources were explicitly recognized as contributors. The agreement also sought to explore "cooperative relationships" with New York, Delaware, and West Virginia to reach out to the three additional states that have land area within the watershed. Although progress had been made in terms of nutrient and sediment reduction, the Bay's heath did not drastically improve during the 1990s (Fig. 1).

The 2000 agreement, which still only included Virginia, Maryland, Pennsylvania, and Washington, DC, established load reductions for sediment and chemical contaminants as well as renewing the $40 \%$ reduction in $\mathrm{N}$ and $\mathrm{P}$ goals from 1985 levels (Chesapeake Executive Council, 2000). This agreement also included specific population goals for certain species including blue crabs, menhaden, and submerged aquatic vegetation (SAV). Once again, the outcomes of this process were not binding; however, a few months later in 2000 , a Memorandum of Understanding (MOU) was signed with the EPA by all six states in the watershed and Washington, DC, in response 


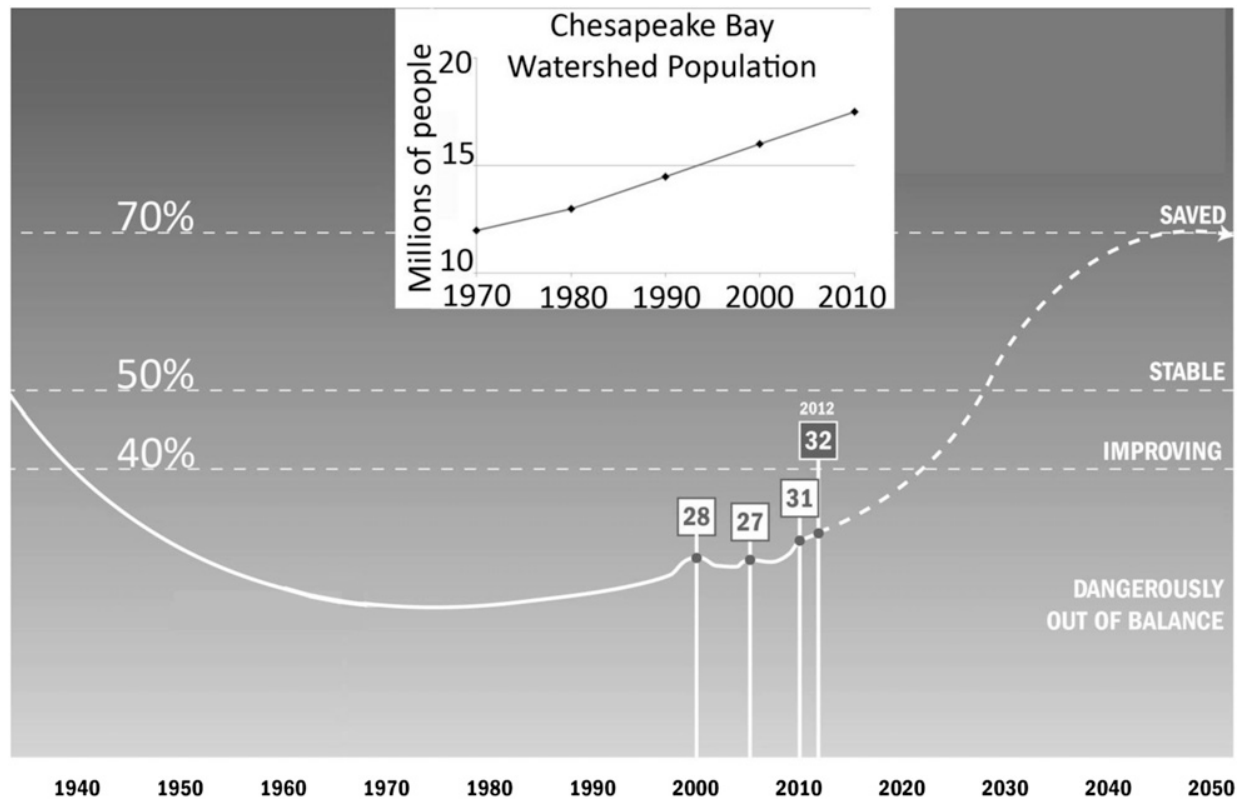

Fig. 1. Health of the Chesapeake Bay over time based on a number of indicators including nutrient inputs, submerged aquatic vegetation health, and oyster and blue crab populations. (Inset) Human population of the Chesapeake Bay watershed over time (Chesapeake Bay Foundation, 2012, used with permission).

to the EPA being taken to court for its failure to protect the Bay under the Clean Water Act. This MOU outlined the TMDL strategy that would be implemented if the Bay and its tributaries were not removed from the impaired waters list by 2010 (Zilioli, 2011). This agreement was binding and would require states to implement and comply with nutrient and sediment load reductions (Chesapeake Executive Council, 2000).

Every year, the Bay's health has been rated by a number of different health parameters such as oyster health, blue crab populations, and SAV cover to determine the progress that had been made in restoring the health of the Bay (Fig. 1). By the end of the decade, restoration efforts had largely failed, and the EPA was once again taken to court by several advocacy groups in 2009, because it was not moving forward to implement the TMDL strategy as required in the MOU (Zilioli, 2011).

In 2009, President Obama signed executive order 13508 to protect and restore the Chesapeake Bay and its tributaries. This executive order established a Federal Leadership Committee to oversee the development and coordination of the various programs and organizations involved in the restoration efforts and increased funding and accountability. As part of the TMDL process, both short- and long-term goals have been set for each of the 92 watershed segments. In the short term, there are milestones that must be met every 2 years with defined consequences for failure to meet these targets. For example, during the first 2 years, specific water quality, stream restoration, agricultural, atmospheric, stormwater, and septic outcomes must be achieved. By 2017, a 60\% reduction goal must be met for N, P, and sediment. If specific goals are not met by each state, increased pollution reduction measures will need to be implemented in the remaining years. The ultimate goal is that by 2025 , the Bay will be removed from the impaired waters list, achieve a "health" score of 40 or more, and be on its way to becoming cleaner and more stable over the long term.

Although the TMDL process indicates what nutrient reductions need to occur over a given timeframe, how those reductions are met is under the jurisdiction of each state. A state may pass additional laws, assess additional taxes, or fund additional projects to meet reduction goals. In the past, efforts have mainly focused on point sources such as wastewater treatment plants because reductions are easier to measure and can also be regulated as part of the National Pollutant Discharge Elimination System (NPDES) permit program. The NPDES regulates all point sources, including wastewater treatment plants, and can deny new permits and/or renewals if a watershed is not meeting its loads. It is likely that there will be an increased focus on non-point sources in the coming years, which will include both agricultural and urban sources. The question remains what types of regulations may be implemented and how would they impact both farmers and residents of each state. It is important for ornamental growers in any impaired watershed to understand the TMDL process and the potential impacts that nutrient, chemical, and sediment restrictions could have on their operation.

\section{RESTORATION PROGRESS}

Since Bay restoration began in 1983, a number of changes have been made in an effort to restore this ecosystem. State legislatures have passed numerous bills to raise and distribute funds for the cleanup effort and set limits on pollution and fisheries catches. For example, Maryland passed a law requiring all agricultural operations (including ornamental operations) with a gross income of $\$ 2500$ or more to complete and submit a nutrient management plan for $\mathrm{N}$ and $\mathrm{P}$ and to file yearly reports on $\mathrm{N}$ and $\mathrm{P}$ application on their acreage (Lea-Cox and Ross, 2001; Lea-Cox et al., 2001). In addition organizations like the Chesapeake Bay Foundation ( $<\mathrm{http}: / /$ www.CBF.org $>$ ) have helped educate and provide information on restoration efforts and progress.

A number of factors have slowed progress on restoring Bay health, including economic, environmental, and societal factors. Population increase in the watershed is another factor, which increases nutrient loading rates. On average, 150,000 people are born or move into the watershed each year, which increases pollution loads and makes reaching nutrient and sediment reduction targets more difficult (Fig. 1 inset). Since the first Bay agreement was signed in 1983, the population in the watershed has increased from $\approx 13$ million to 17 million residents and is expected to reach 20 million by the year 2030 . These additional people translate to higher inputs into air sheds through vehicle emissions and power plant operations, increased load on wastewater treatment plants, more houses, and more fertilizer applied to suburban areas.

\section{WHAT IS A TOTAL MAXIMUM DAILY LOAD?}

A TMDL is a numeric scientific estimate of the maximum daily amount of any pollutant that a body of water can receive and still meet water quality standards. Pollutant loads can be established for any number of compounds including heavy metals, fecal coliform, pesticides, and nutrients. The goal of a TMDL is to reduce pollution loads enough to remove a water body from the 303(d) impaired 
waters list (U.S. EPA, 2010b). It is important to understand that a TMDL accounts for both point and non-point sources flowing into a waterway, so a TMDL can either be met by reducing point source loads, non-point source loads, or a combination of the two.

Point sources are easier to quantify and are often regulated at the state and federal level through NPDES permitting. Non-point sources, including agricultural runoff, are diffuse and scattered throughout a watershed, making them much more difficult to identify and manage when compared with point sources. A variety of nutrient application rates, sediment reduction practices as well as other agricultural BMPs are in place to reduce nutrient and sediment infiltration and to decrease nutrient runoff. All of these factors must be taken into account to assess the real impact of a nutrient or sediment source on its tributary.

The majority of the land area in the Chesapeake Bay watershed is forested area (64\%), whereas agriculture accounts for $24 \%$ of the area and $8 \%$ is considered urban (Fig. 2). It is not clear where suburban land area is allocated in this diagram. From this information, it appears that agriculture is the largest human influenced land use type in the watershed, which may indicate the relative importance of agriculture and management of nutrient and sediment pollution inputs to the watershed.

Agriculture, which includes ornamental plant production, currently accounts for the largest contributed loads for N, P, and sediment reaching surface waters in the Bay watershed (Fig. 3). Manure accounts for $17 \%$ of the $\mathrm{N}$ and $38 \%$ of the $\mathrm{P}$ reaching surface waters, whereas fertilizer accounts for $15 \%$ and $28 \%$, respectively. Human $\mathrm{N}$ contributions (wastewater, septic, and urban) are almost equivalent to the amount applied by agriculture (manure, fertilizer, and agricultural atmospheric contributions) at $34 \%$ and $38 \%$, respectively. Although agriculture makes a substantial contribution to N, P, and sediment into surface waters, inputs from non-agricultural sources (both human and industrial) cannot be ignored.

Although the watershed encompasses land area in six states and the District of Columbia, each state does not have an equal amount of reduction that needs to occur as part of the

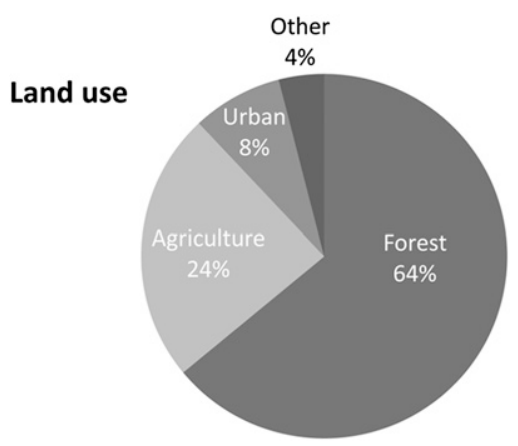

Fig. 2. Area of the Chesapeake Bay watershed broken down by land use types (Chesapeake Bay Foundation, 2010, used with permission).
TMDL process (U.S. EPA, 2010b). Table 1 shows the amount of N, P and sediment that needs to be reduced by each state together with the percentage of the reduction that each state accounts for, and how much of that goal they have reached, as of 2011. The first column totals the load reduction for which each state is responsible. The total percent reduction (column 2 for $\mathrm{N}, \mathrm{P}$, and sediment) represents the total mass load reduction each state is responsible for, whereas the percent reduced to date (column 3) represents the percentage of the total mass reduction goal each state has met. For example, Virginia is responsible for reducing 52.5 million pounds of $\mathrm{N}$ or $27.4 \%$ of the 191.7 million pounds total. To date, Virginia has reduced $\mathrm{N}$ loading by $38 \%$, or 20.0 million pounds reduced, and is required to reduce $\mathrm{N}$ loading by an additional 32.4 million pounds to reach their goal.

For N, P, and sediment loads, Pennsylvania, Virginia, and Maryland account for the majority of pollutants that must be removed, which roughly relates to their respective land area. Pennsylvania has to reduce $\mathrm{N}$ inputs by more than any other state (78.8 million pounds), whereas Virginia has to reduce the most P (6.5 million pounds) and sediment (3.3 trillion pounds) by 2025. Pennsylvania, Virginia, and Maryland each have to make large reductions in $\mathrm{N}, \mathrm{P}$, and sediment over the next 12 years to meet interim and final goals. New York, West Virginia, Delaware, and Washington, DC, make up a relatively small portion of the overall reduction and cumulatively account for $10.1 \%$ of the $\mathrm{N}$, $11.5 \%$ of the $\mathrm{P}$, and $10.8 \%$ of the sediment that must be remediated in the upcoming years. Reductions in nutrient and sediment inputs will likely come from a variety of sources. Some wastewater treatment plants have been retrofitted with technology upgrades, aimed at long-term reduction of nutrient inputs to waterways. In 2003, it was reported that 234 of the 265 treatment plants in Maryland, New York, Pennsylvania, and Washington, DC, had average $\mathrm{N}$ discharge rates above $5.1 \mathrm{mg} / \mathrm{L}$ with a cost of upgrading to less than $3 \mathrm{mg} / \mathrm{L}$ estimated at $\$ 4.4$ billion, which would achieve a $20 \%$ reduction in $\mathrm{N}$ loads reaching the Bay (Chesapeake Bay Foundation, 2003).

As discussed previously, agriculture accounts for $24 \%$ of the acreage in the watershed. Implementation of BMPs has had and will continue to have major implications for reducing nutrient and sediment runoff. Agricultural operations have implemented a number of management practices over the years, sometimes without governmental support (e.g., cost share or conservation payments) to offset the cost of implementing those practices. If growers did not receive any incentives for implementing these improvements, they are often not captured in Chesapeake Bay model (Erhart, 2010), and agriculture is therefore not receiving credit for those practices. Figure 4 shows the relative expense associated with implementing various $\mathrm{N}$ reduction technologies. It is typically less expensive to implement best management or conservation (e.g., buffer area) practices in agriculture compared with point sources where remediation technology is often more expensive. Nutrient remediation often comes at a cost for growers through capital and maintenance expenditure and, for some of the technologies, by removing land from production, for example installation of wetlands or

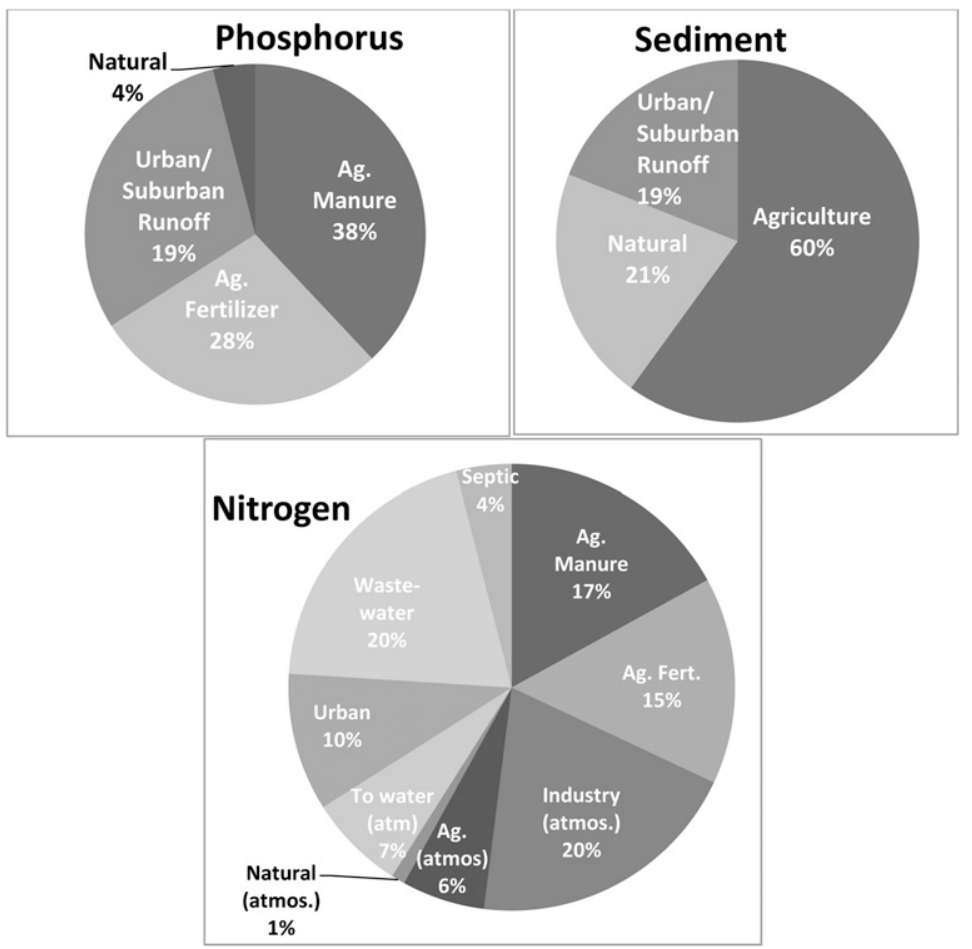

Fig. 3. Nitrogen, phosphorus, and sediment loads to the Chesapeake Bay and its tributaries by source. Figure adapted from U.S. Environmental Protection Agency (2010a). 
Table 1. Nitrogen, phosphorus, and sediment reductions by state in the Chesapeake Bay watershed based on 1985 values. ${ }^{\mathrm{z}}$

\begin{tabular}{|c|c|c|c|c|c|c|c|c|c|c|}
\hline \multirow[b]{2}{*}{ State } & \multirow[b]{2}{*}{ Acreage $(\%)$} & \multicolumn{3}{|c|}{ Required nitrogen reduction } & \multicolumn{3}{|c|}{ Required phosphorus reduction } & \multicolumn{3}{|c|}{ Required sediment reduction } \\
\hline & & $\begin{array}{c}10^{6} \\
\text { pounds }\end{array}$ & $\begin{array}{c}\text { Total } \\
\text { reduction }(\%)\end{array}$ & $\begin{array}{c}\text { Reduced } \\
\text { to date }(\%)\end{array}$ & $\begin{array}{c}10^{6} \\
\text { pounds }\end{array}$ & $\begin{array}{c}\text { Total } \\
\text { reduction }(\%)\end{array}$ & $\begin{array}{c}\text { Reduced } \\
\text { to date }(\%)\end{array}$ & $\begin{array}{c}10^{6} \\
\text { pounds }\end{array}$ & $\begin{array}{c}\text { Total } \\
\text { reduction }(\%)\end{array}$ & $\begin{array}{c}\text { Reduced } \\
\text { to date }(\%)\end{array}$ \\
\hline Pennsylvania & 35 & 78.8 & 41.1 & 37 & 3.60 & 24.7 & 40 & 1,945 & 26.5 & 35 \\
\hline Virginia & 34 & 52.5 & 27.4 & 38 & 6.50 & 44.5 & 44 & 3,251 & 44.3 & 34 \\
\hline Maryland & 14 & 41.2 & 21.5 & 46 & 2.80 & 19.2 & 48 & 1,350 & 18.4 & 28 \\
\hline New York & 10 & 8.4 & 4.4 & 40 & 0.64 & 4.4 & 49 & 304 & 4.1 & 19 \\
\hline West Virginia & 6 & 5.0 & 2.6 & 21 & 0.64 & 4.4 & 29 & 373 & 5.1 & 28 \\
\hline Delaware & 1 & 3.4 & 1.8 & 36 & 0.28 & 1.9 & 43 & 100 & 1.4 & 17 \\
\hline Washington, DC & 0.1 & 2.4 & 1.3 & 62 & 0.12 & 0.8 & 37 & 17 & 0.2 & 3 \\
\hline Total & & 191.7 & & 40 & 14.60 & & 43 & 7,340 & & 32 \\
\hline
\end{tabular}

zThe percent of total reduction is each state's contribution to the total Bay-wide reduction, whereas percent reduced to date is the amount of reduction achieved for that state as of 2011 .

Adapted from Chesapeake Bay Program. 16 Nov. 2012. <http://www.cbf.org/how-we-save-the-bay/chesapeake-clean-water-blueprint/pollution-limits-by-state>.

vegetative buffers. Additional areas for reduction include remediation of urban/suburban runoff and air sheds, which could remove large inputs of nutrients over large areas (Fig. 3).

\section{MOVING FORWARD}

In 2011, a Chesapeake Bay agriculture expert panel was formed, which included research and extension members from throughout the watershed, representing all sectors of agriculture. Several goals were outlined for the committee, whose primary task was to gather information about agriculture across the entire watershed and to increase collaboration and information-sharing about practices among states. By sharing information on each state's approach to nutrient and BMPs, areas for improvement could be identified and information transferred on how best to move forward with BMP implementation to ultimately reach TMDL goals. Another goal of the expert panel was to provide additional information to the Chesapeake Bay Scenario Builder model and the Chesapeake Bay Program's Watershed Model - Hydrological Simulation Program in Fortran to better model agricultural practices (particularly ornamental practices) and their resultant nutrient and sediment losses. The results from the Chesapeake Bay model simulations are used to determine where nutrient reductions should be focused in various segments of the Bay. Simulating ornamental (nursery and greenhouse) production practices is problematic as a result of the wide variety of irrigation (e.g., microirrigation, overhead sprinkler, and boom), fertilizer (e.g., different formulations, rates, and application timing), and management (e.g., vegetated buffers, substrate type, sediment/containment pond) practices in the watershed.

Our specific goal as the "ornamental industry" working group within this committee is to inform the Chesapeake Bay modelers about how the model can be adapted to better model the inputs and practices used by greenhouse and nursery operations. In Maryland, specific water and nutrient management information is available through the nutrient management plans and annual reporting forms, which are collected by the Maryland Department of Agriculture. However, this information is not shared with external parties or agencies, even in aggregate form. As a result of this inaccessibility, detailed nutrient and irrigation application information was voluntarily contributed by 49 growers in Maryland $(\approx 15 \%$ of total nursery and greenhouse operations in Maryland) in a study conducted by Majsztrik (2011). This information was collected and secured by an Institutional Review Board protocol, which guarantees that no individual operational data are disclosed (Majsztrik, 2011). This detailed database of practices has provided numerous insights into water and nutrient application practices by growers in field (soil production), container-nursery, and greenhouse production systems (Majsztrik, 2011). Furthermore, the production system models that were developed by Majsztrik (2011) have allowed us to test a number of different $\mathrm{N}, \mathrm{P}$, and water application scenarios, which has allowed for numerous insights into how we can reduce $\mathrm{N}$ and $\mathrm{P}$ loading with reduced nutrient application rates to targeted species in different operations when combined with better water management practices.

We are also working to include nursery and greenhouse extension specialists from other states in the working group to ensure that we are synchronizing our efforts throughout the Bay watershed, and with the Chesapeake Bay modelers to resolve the lack of specificity with regard to inputs and management practices for nursery and greenhouse operations for the 2017 iteration of the model. Current land use allocation in the model is based on National Agriculture Census data (U.S. Department of Agriculture, 2009). The main limitation with this census data are that field, container-nursery, and greenhouse production is based on categories such as woody perennial, floricultural crops, etc., which do not relate to how those broad categories of plants are produced by different segments of the industry and which have very different nutrient and irrigation application practices. Majsztrik (2011) reported average yearly application rates ranging from 62 to $800 \mathrm{~kg}$ $\mathrm{N} / \mathrm{ha}$ and 17 to $251 \mathrm{~kg} \mathrm{P} / \mathrm{ha}$ in containernursery production compared with 7 to $67 \mathrm{~kg}$ $\mathrm{N} / \mathrm{ha}$ and zero to $19 \mathrm{~kg} \mathrm{P} / \mathrm{ha}$ in field operations. Application rates are closely tied to plant densities in production, which are reflected in the greater application rates for container-nurseries. Majsztrik (2011) also reported that there are great disparities in application rates among growers of the same crops and container sizes.

Currently, a single $\mathrm{N}$ and $\mathrm{P}$ application rate (similar to the higher rates previously described) is attributed to all crop production in greenhouse, container-, and field nursery production areas in the Chesapeake Bay model, although we would estimate $\approx 75 \%$ of the 20,500 acres of ornamental production area in Maryland is under field production with much lower average $\mathrm{N}$ and $\mathrm{P}$ inputs (as noted previously). We therefore believe that disproportionate amounts of $\mathrm{N}$ and $\mathrm{P}$ applications are currently being attributed to this sector of agriculture, although they represent a very small proportion of total nutrients applied by agriculture in the watershed. Although we would assume nutrient application rates in ornamental operations are similar throughout the watershed, we are not certain of this. Thus, to obtain more accurate land-use data, we are planning to survey Maryland nursery and greenhouse growers about their specific land acreage used in production during 2013. This will help to resolve uncertainties in the Chesapeake Bay model and allow us to more accurately estimate $\mathrm{N}$ and $\mathrm{P}$ application rates for the industry in Maryland, which may be generally applied to the rest of the watershed.

We also intend to incorporate additional BMPs into the Chesapeake Bay model for ornamental growers, including lower fertilizer rates, vegetated buffer strips, cyclic irrigation, and SRF sources. Currently, the only management practice that can be used for nutrient reduction in these operations is $100 \%$ containment of runoff, which is unrealistic for many growers as a result of lost production area, expense, and disease management issues. There is a two-step process for inclusion of a specific BMP in the Chesapeake Bay model. The first step is acceptance of an approved "interim" BMP. The effectiveness of this interim BMP has to be rigorously documented for acceptance as a "final" BMP. This is typically accomplished with a targeted research study or review of previously published research studies, which quantify load reductions for that particular BMP. There are a number of established BMPs in ornamental operations that are known to reduce nutrient and/or sediment runoff, but nutrient reductions from some of these BMPs have not been 


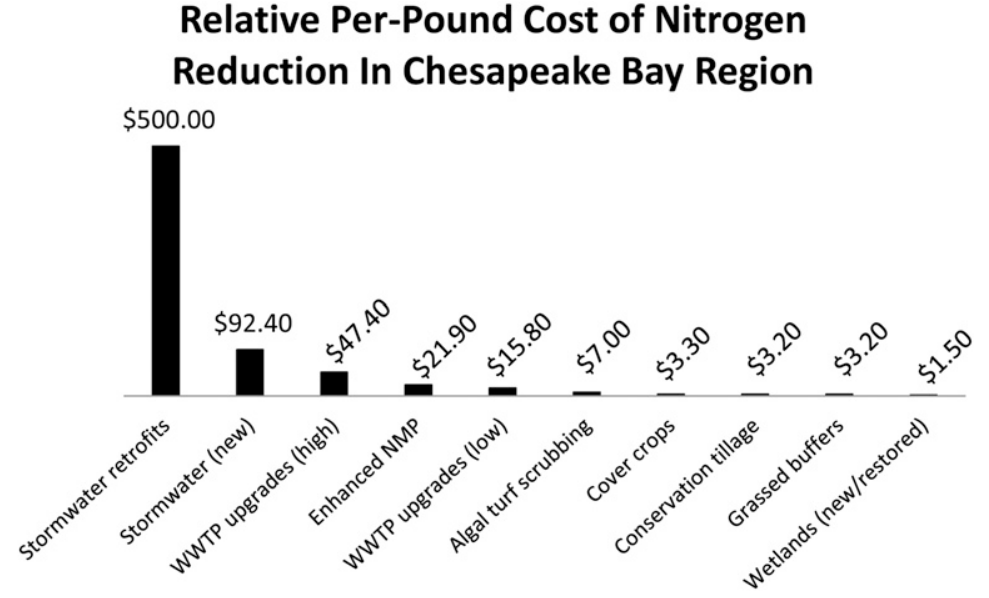

Fig. 4. Relative cost of remediating 1 pound of nitrogen (Data from Chesapeake Bay Foundation, 2012 , used with permission).

quantified with rigorous experimentation. It is possible that we can use existing enterpriselevel models to quantify load reductions with reduced cost and time requirements for verifying those BMPs (Majsztrik, 2011). These models were designed specifically for nursery and greenhouse operations and incorporate many of the current management practices (e.g., in-field buffer strips, slow-release fertilizer sources, low or no-P fertilizer blends) and may be useful for gaining interim and final approval for a number of management practices through the Chesapeake Bay Agricultural Committee. This process could provide reasonable estimates of nutrient and sediment reductions on a time scale that is reasonable for inclusion of the BMPs in the 2017 iteration of the model. It is imperative to include these approved BMPs in the Chesapeake Bay model to address the disconnect between BMPs that are already in use/in place as reflected in nutrient management plans, which have already been approved, and the data being used in the Chesapeake Bay model.

\section{NUTRIENT TRADING}

Nutrient trading is another opportunity, which may have the potential to reduce nutrient loads to the Bay and provide growers with an additional income source. Nutrient trading is a way to offset urban and industrial inputs across the watershed. It allows agricultural producers who are not applying excessive amounts of nutrients or who have implemented BMPs to reduce nutrient loading to "trade" any available credits with those users who are not currently in compliance with their load limits. One credit is equal to a 1pound reduction in $\mathrm{N}$ reaching surface waters. Nutrient trading is a legal contract where one entity (typically a point source) that is contributing too much of a pollutant pays another entity (typically a non-point source like an agricultural operation) for part of the pollutant load they are not contributing over a certain amount of time. Although nutrient trading is a mechanism available to all agricultural producers, we are focusing on its potential impact for ornamental plant growers, especially field operations who are applying very low $\mathrm{N}$ and $\mathrm{P}$ rates and who have implemented a range of BMPs. The nutrient trading tool ( $<$ http://nutrientnet.mdnutrienttrading.com $>$ ) requires participants to have both a soil conservation plan and a nutrient management plan to complete the required information. The user inputs their historic practices $(\mathrm{N}$ and $\mathrm{P}$ application rates, planting and harvesting time, management practices, etc.) and then inputs changes in practice since 2007 . The trading tool then calculates $\mathrm{N}$ and $\mathrm{P}$ reductions based on those changes in practice. The trading tool also considers an operation's location in the watershed and apportions a "load factor' (from 0 to 1.0) to the calculation of any tradable credits. Growers closer to impaired waters have a higher load factor (e.g., credits $\times 0.7$ ) compared with growers who are further away (credits $\times 0.2$ ). The result is the number of credits that a specific operation has to trade based on their nutrient application rates and conservation practices that are in place and their watershed location. After determining the number of available credits, an independent audit procedure is completed. The audit is typically completed by a certified National Resource Conservation Service technical service provider, who verifies the practices and nutrient application rates that were reported by the farmer based on fertilizer receipts, etc. Once the audit is complete, the credits can be placed in a "marketplace" where the credits are then traded. Another benefit of the nutrient trading tool is that once all of the information is entered in the online system, a grower can easily see how any future changes such as installing buffer strips or reducing fertilizer application rates and/or timings would impact the number of tradable credits.

Two types of contracts are currently being used: short and long term. Short-term contracts ( 5 to 10 years) could be used by wastewater treatment plants and other industrial entities to temporarily offset higher pollution loads until infrastructure or other improvements can be made. These types of credits are currently earning $\$ 30$ to $\$ 50$ per credit per year, guaranteed for the life of the contract (Robert Ensor, Howard County, MD, Soil Conservation District, District Manager, personal communication). Currently, only N credits are being traded in the marketplace. It is likely that $\mathrm{P}$ credits will be worth significantly more because $\mathrm{P}$ is much more difficult to remediate compared with $\mathrm{N}$ (Hansen et al., 2002). Long-term (greater than 10-year) contracts are being used to remediate sources of $\mathrm{N}$ and $\mathrm{P}$ pollution that are not likely to change in the short term such as new septic tank installations in rural areas. These contracts could be for 50 or more years with payouts of $\$ 5,000$ to $\$ 50,000$ per credit for $\mathrm{N}$ (Robert Ensor, Howard County, MD, Soil Conservation District, District Manager, personal communication). Long-term credits would most likely apply to more permanent practices such as conservation easements.

Nutrient trading therefore has the potential to not only increase a grower's revenue by paying an operation for positive changes that have been implemented in their practices, but also can be used to share the cost of, or incentivize, additional nutrient reduction practices. For example, a buyer might pay for part or all of the cost of additional buffer strips or other changes in practice and then pay a yearly amount for the grower to maintain the buffer in addition to the money they are paying for the credits. This would allow the grower to install and maintain additional BMPs at low or no cost during the contract period.

\section{HOW MANY CREDITS CAN BE GAINED?}

We have worked with a few growers to better understand how the nutrient trading tool works for nursery operations. For example, one of the operations has $\approx 150$ acres of total production area with $\approx 75$ acres under ornamental field production and 75 acres currently in a corn/soybean rotation. This operation is incrementally taking a number of acres out of corn/soybean rotation each year to put into field production. The initial 2007 conditions for this operation were $\approx 10$ acres of nursery with the remaining 140 acres in corn/soybean. By converting all acres from current corn/soybean to field production with vegetative buffer strips and lower fertilizer inputs, a total of $750 \mathrm{~N}$ credits and $300 \mathrm{P}$ credits were generated, or $\approx 5 \mathrm{~N}$ credits/acre and $2 \mathrm{P}$ credits/acre. At the current price of $\$ 30$ to $\$ 50$, that would equate to $\$ 22,500$ to $\$ 37,500$ additional income per year for all $\mathrm{N}$ credits. If the $\mathrm{P}$ credits are worth say $\$ 100$ to $\$ 500$, that would be an additional $\$ 30,000$ to $\$ 150,000$ per year for those credits. To be clear, there is currently no $\mathrm{P}$ trading within the Chesapeake Bay, so these values per credit are for illustration only.

\section{NUTRIENT TRADING QUESTIONS}

A number of outstanding questions about nutrient trading still need to be clarified. It is not clear how the models underlying the 
nutrient trading tool were developed, calibrated, or validated. These steps have a large impact on the final results. It is also unclear what baseline values should be used. For the example listed, should credits for changing from a corn/soybean rotation to field be based on historic practice, the fertilization rates the grower applied last year, or the average of the last 5 or 10 years? Alternately, should credits be based on the maximum amount of nutrients that a grower could have applied to that crop compared with current practice? These scenarios would each have different outcomes in regard to tradable credits. The industry needs a clear set of policies and guidelines before growers are likely to widely adopt trading.

Uncertainties also exist for growers who have taken a number of steps to reduce their nutrient loading such as reduced nutrient inputs, installed sediment/retaining ponds, vegetated ditches, etc., but did not receive cost share and did so before the 2007 cutoff. This is the case for many ornamental operations, which means they do not have any credits to trade because they made changes to their operation too early. This does not seem entirely equitable, especially because these changes are not accounted for in the Chesapeake Bay Model, if they were not cost shared, and therefore are not included in the current model.

On a more practical level, growers have questions about the current and ultimate value of $\mathrm{N}$ or $\mathrm{P}$ credits. The current system is driven by the buyer, who determines the price they will pay for a credit, and the seller (farmer) decides if they are willing to accept that price (i.e., auction approach). However, ideally there would be clarity in this process so that buyers and sellers know the prices of previous agreements (e.g., futures market). This would address equity issues and allow all parties to receive a fair price. Participating growers must understand that when they sign a contract, they are bound by that agreement to apply only that amount of fertilizer or to implement and maintain the agreed-on management practices for the length of the contractual period. They need to make sure that they will be able to remain profitable and maintain fertility during that time period.

\section{CONCLUSIONS}

Regulations in the Chesapeake Bay watershed are not likely to decrease in the coming years, because population and development further tax an already stressed Chesapeake Bay watershed. To reach water quality goals in this region, it is likely that current regulations will be continued and additional nutrient and sediment reduction goals added, where necessary. As researchers, we will continue to work with growers, the Chesapeake Bay modelers, and regulators on these and other issues to increase the accuracy of information, to help identify ways to reduce the impact of ornamental growing operations on the environment, and to help growers understand and comply with changing regulations.

\section{Literature Cited}

Chesapeake Bay Foundation. 2003. Sewage treatment plants: The Chesapeake Bay Watershed's second largest source of nitrogen pollution. 16 Nov. 2012. <http://www.cbf.org/document. doc?id $=143>$.

Chesapeake Bay Partnership. 1983. The Chesapeake Bay Agreement of 1983, Chesapeake Bay Partnership, Washington, DC. 5 Dec. 2012. <http://www.chesapeakebay.net/content/ publications/cbp_12512.pdf>.

Chesapeake Executive Council. 1987. Chesapeake Bay Agreement, Chesapeake Bay Program, Annapolis, Maryland. 5 Dec. 2012. <http://www. chesapeakebay.net/content/publications/cbp_ 12507.pdf>.

Chesapeake Executive Council. 1992. Amendments to the Chesapeake Bay Agreement, Chesapeake Bay Program, Annapolis, MD. 12
Nov. 2012. <http://www.chesapeakebay.net/ content/publications/cbp_12507.pdf>.

Chesapeake Executive Council. 2000. Chesapeake 2000, Chesapeake Bay Program, Annapolis, MD. 1 Dec. 2012. <http://www.chesapeakebay. net/content/publications/cbp_12081.pdf>.

Erhart, M. 2010. Chesapeake Bay Foundation statement on Farm Bureau opposition to the Chesapeake Clean Water Act. Press release: 11 Aug. 2010.

Hansen, N.C., T.C. Daniel, A.N. Sharpley, and J.L. Lemunyon. 2002. The fate and transport of phosphorus in agricultural systems. J. Soil Water Conserv. 57:408-425.

Lea-Cox, J.D. and D.S. Ross. 2001. A review of the Federal Clean Water Act and the Maryland Water Quality Improvement Act: The rationale for developing a water and nutrient management planning process for container nursery and greenhouse operations. Journal of Environmental Horticulture 19:226-229.

Lea-Cox, J.D., D.S. Ross, and K.M. Teffeau. 2001. A water and nutrient management planning process for container nursery and greenhouse production systems in Maryland. Journal of Environmental Horticulture 19:230-236.

Majsztrik, J. 2011. Modeling nitrogen, phosphorus and water dynamics in greenhouse and nursery production systems. PhD diss., University of Maryland, College Park, MD.

U.S. Department of Agriculture. 2009. 2007 Census of Agriculture. National Agricultural Statistics Serv., Washington, DC.

U.S. Environmental Protection Agency. 2010a. Chesapeake Bay Phase 5.3 Community Watershed Model. EPA 903S10002-CBP/TRS10303-10010. U.S. Environmental Protection Agency, Chesapeake Bay Program Office, Annapolis, MD.

U.S. Environmental Protection Agency. 2010b. Draft Chesapeake Bay total maximum daily load. Section 9. 15 Nov. 2012. <http://www.epa.gov/ reg3wapd/tmdl/ChesapeakeBay/drafttmdlexec. html>.

Zilioli, E. 2011. Building a better bay through litigation: National association of home builders files suit challenging the Chesapeake Bay clean water act TMDL. Eastern Water Law and Policy Reporter Aug. 2011. p. 215-218. 